\title{
First report of Olpidium bornovanus and $O$. virulentus on watermelon in Sardinia, Italy
}

\author{
Nicola Schianchi ${ }^{1}$ - Leonardo Oggiano ${ }^{2} \cdot$ Gabriele Chilosi $^{3} \cdot$ Virgilio Balmas $^{1}$ \\ Received: 13 December 2018 / Accepted: 30 April 2019/Published online: 8 May 2019 \\ (C) Società Italiana di Patologia Vegetale (S.I.Pa.V.) 2019
}

Keywords Olpidium spp. $\cdot$ Root rot $\cdot$ Watermelon

In recent years the cultivation of watermelon (Citrullus lanatus L.), an economic important resource in Sardinia (Italy), has been subjected to significant losses in yield and quality due to the spread of symptoms represented by root rot and vine decline. Olpidium spp. and Monosporascus cannonballus Pollak and Uecker have recently been associated with similar symptoms on melon in Central Italy (Aleandri et al. 2017). During summer 2018, in the producing area of Valledoria( $\sim 80$ ha), northern Sardinia, 10 symptomatic plants were sampled in a field of 6 ha, where $80 \%$ of the plant showed symptoms of collapse. From symptomatic roots no M. cannonballus was isolated. Olpidium spp. was baited by growing watermelon (cultivar Melania) plants in two different soils collected adjacent to roots of symptomatic plants. Plants grown in sterilized soil were used as a negative control. Plants grown in infested soil showed after 40 days root browning, foliage chlorosis followed by plant wilt. Twelve plants were used in each thesis. Baited roots were analysed for the presence of Olpidium spp. by morphological methods as described by Aleandri et al. (2017). Stellate resting spores referred to as $O$. virulentus (Sahtiyanci) Karling and O. bornovanus (Sahtiyanci) Karling smooth-walled resting spores with a honeycomb-like pattern were observed in diseased roots. Neither disease symptoms nor Olpidium spores were observed

\section{Virgilio Balmas}

balmas@uniss.it

1 Dipartimento di Agraria, Sezione di Patologia Vegetale ed Entomologia, Università degli Studi di Sassari, Viale Italia 39, 07100 Sassari, Italy

2 Società Cooperativa Agricola Valle del Coghinas, S.M. Coghinas, 07030 Sassari, Italy

3 Dipartimento per l'Innovazione nei Sistemi Biologici, Agroalimentari e Forestali, Università degli Studi della Tuscia, Via S. Camillo de Lellis, 01100 Viterbo, Italy from the plants grown in sterilized soil. For molecular analysis, DNA was extracted from watermelon roots, following the protocol described by Aljanabi and Martinez (1997) and tested by multiplex PCR to confirm Olpidium spp. identification as described by Herrera-Vásquez et al. (2009). Amplified PCR products, corresponding to O. bornovanus $(977$ bp fragment size) and $O$. virulentus (579 bp fragment size) were detected. $O$. bornovanus and $O$. virulentus are rootinfecting plant pathogens of melon (Aleandri et al. 2017), and previously detected in watermelon roots in Spain (Herrera-Vásquez et al. 2009). To our knowledge, this is the first report of $O$. virulentus and $O$. bornovanus occurrence on watermelon in Italy.

Acknowledgements This work was supported by project grant from Regione Sardegna (delibera della Giunta Regionale n. 52/101).

\section{References}

Aleandri MP, Martignoni D, Reda R, Alfaro-Fernandez A, Font MI, Armengol J Chilosi G (2017) Involvement of Olpidium bornovanus and $O$. virulentus in the occurrence of melon root rot and vine decline caused by Monosporascus cannonballus in Central Italy. J Plant Pathol 99:169-176

Aljanabi SM, Martinez I (1997) Universal and rapid salt-extraction of high quality genomic DNA for PCR-based techniques. Nucleic Acids Res 25(22):4692-4693

Herrera-Vásquez JÁ, del Carmen Cebrián M, Alfaro-Fernández A, del Carmen Córdoba M, Jordá C (2009) Multiplex PCR assay for simultaneous detection and differentiation of Olpidium bornovanus, O. brassicae and O. virulentus. Mycol Res 113:602-610

Publisher's note Springer Nature remains neutral with regard to jurisdictional claims in published maps and institutional affiliations. 